\title{
ANTIMICROBIAL ACTIVITY OF CRUDE EXTRACTS OFGARCINIA
}

\section{MANGOSTANA FRUIT PERICARP}

\section{S. S. Deo ${ }^{1}$, F. Inam ${ }^{1}$, N.S.Kadam*}

Department Of Chemistry, Institute Of Science, Nagpur - 440010 India

* Datta Meghe Institute Of Engineering Technology \& Research

Wardha442001 India

*Corresponding author:Email-neelamkadam2010@rediffmail.com

\begin{abstract}
The antimicrobial activity of crude Petroleum ether,dichloromethane and Chloroform extracts of Garcinia mangostana fruit pericarp against gram positive, gram negative and antifungal strains were evaluated at different concentrations to find the zone of inhibition. The crude Petroleum ether and Chloroform extract of Garcinia mangostana showed strong antimicrobial activity against Staphylococcus aureus and Escherichia coli (Bacterial strains) and crude dichloromethane extract showed strong antimicrobial activity against Aspergillis awamorii (Fungal strain).
\end{abstract}

Keywords: Garcinia mangostana, Antimicrobial, Bacterial strains, Fungal strains,Antimicrobial.

\section{Introduction}

Medicinal plants are widely used for curing various diseases since traditional times. Different plant parts like root, leaves, stems, seeds or even whole plants are known to have therapeutic potentials ${ }^{1}$. Medicinal plants have been used as preservatives, in pharmaceutics, natural therapies etc. There is a greater demand for medicinally important plants $\&$ cultivation of such plants is recommended. About 100 plant species are involved in $25 \%$ of all prescribed drugs in advanced countries ${ }^{2}$. Among all families of plant kingdom members of Guttiferae have been used for centuries in folk medicine. Garcinia mangosteen, which is widely used in Ayurveda, have known to possess enormous medicinal potential.

Fatal infectious diseases are the world's leading cause of concern with drug \& antibiotic resistant human pathogenic bacteria commonly 
reported from all over the world ${ }^{5-9}$. Multiple drug resistance has developed due to the indiscriminate use of commercial antimicrobial drugs commonly used in the treatment of infectious disease ${ }^{10}$. There is a constant need for new and effective therapeutic agents. There is a need to develop alternative newly synthesized antimicrobial substances or substance from other sources including plants ${ }^{11}$. With increasing use of drugs, microorganisms are attaining resistance to commonly used antibiotics, which leads to downfall of effectiveness of conventional medicines and therefore, search for new antimicrobial agents has become necessary ${ }^{12}$. Plants having antimicrobial activity have attracted attention in recent years ${ }^{13-15}$. The plant G. mangosteen is one of the most employed medicinal plants \& a source of extracts with strong antibacterial and antioxidant properties. G. mangosteen species are used as effective drugs for many applications in folk medicine especially in Asian Countries ${ }^{16 .}$

\section{Present Work}

Modern day science has recently begun to appreciate the incredible, nutrient-rich value of various plant extracts and its widereaching, health-promoting properties. The present study was to evaluate the antimicrobial activity of extracts of Garcinia mangostana fruit, on selected enteric pathogens.

\section{Experimental Section:}

The shade dried Garcinia mangostana fruit was ground to powder for extraction. This powder was then charged into soxhlet apparatus and extraction was carried out with following solvents with increasing polarity. 
1. Petroleum Ether $\left(60-80^{\circ} \mathrm{C}\right)$

2. Dichloromethane

3. Chloroform

The dried plant powder (approx.50 g at a time) was charged into soxhlet apparatus and extraction was carried out continuously for about 24 hours. Each extract was concentrated using rotary vaccum evaporator and residue was collected in glass bottles and extracts were selected for further analysis. Test organisms taken for study of antimicrobial activity were Staphylococcus aureus, Escherichia coli, Aspergillis awamorii.

\section{Determination of Zone of Inhibition:}

Test solution was prepared with known weight of extract in dimethyl sulphoxide (DMSO) and diluted suitably to give the resultant concentration of 100,250 and $500 \mu \mathrm{g} / \mathrm{ml}$. Whatman no. 1 sterile filter paper discs $(6 \mathrm{~mm})$ were impregnated with solution and allowed to dry at room temperature.

In vitro antibacterial activity was determined by using Mueller Hinton Agar while in vitro antifungal activity was determined by using Sabouraud Dextrose Agar obtained from Himedia Ltd., Mumbai. Twentyfour hours old culture of selected bacteria/fungi was mixed with physiological saline and the turbidity was corrected by adding sterile physiological saline and subcultured on Sabouraud Dextrose and suspended in sterile distilled water to an absorbance of 0.6 at $450 \mathrm{~nm}$. Petri plates were prepared by pouring $10 \mathrm{ml}$ of Mueller Hinton Agar for bacteria and Sabouraud Dextrose Agar for fungi containing microbial culture was allowed to solidify. Five wells of $6 \mathrm{~mm}$ diameter were bored in the medium with the help of sterile cork-borer having $6 \mathrm{~mm}$ diameter and were labelled properly and 100, 250, 500, $\mu \mathrm{g} / \mathrm{ml}$ of the working solution /vehicle and same volume of extraction solvent for control, as well as $25 \mu \mathrm{g} / \mathrm{ml}$ of the standard (Ciprofloxacin) was filled in these wells with the 
help of micropipette. Similar sets were made for other test compounds. The discs were then applied and the plates were incubated at $37^{\circ} \mathrm{C}$ for 24 $\mathrm{h}$ (bacteria), $28{ }^{\circ} \mathrm{C}$ for $72-96 \mathrm{~h}$ (fungi) and the inhibition zone was measured as diameter in four directions and expressed as mean. Amongst all the extracts of Garcinia mangostana, extracts M1and M3 inhibited the action of Staphylococcus aureus and Escherichia coli (Bacterial strains) more as compared to M2 extract at higher concentration, while M2 extract showed larger inhibition zone against Aspergillis awamorii (Fungal strain). Following tables shows the antimicrobial effect of different extracts.

\section{Results and Discussion}

Diameter of the zone of inhibition (ZOI) was measured for the estimation of potency of the antimicrobial substance which is indicated in Table 1.

Table 1 : Observation of Antimicrobial Property of extracts against different pathogenic microorganisms.

\begin{tabular}{|l|l|l|l|l|}
\hline S. No & Test Organism & M1 & M2 & M3 \\
\hline 1. & Staphylococcus aureus & + & + & + \\
\hline 2. & Escherichia coli & + & + & + \\
\hline 3. & Aspergillis awamorii & + & + & + \\
\hline
\end{tabular}

Where, M1, M2, M3 - Petroleum ether, dichloromethane and chloroform extract of G. mangostana. 
Table 2: Zone of inhibition in $\mathrm{mm}$ of different organisms and the different conc. of compounds used(Values below indicate zone of inhibition in $\mathrm{mm}$ )

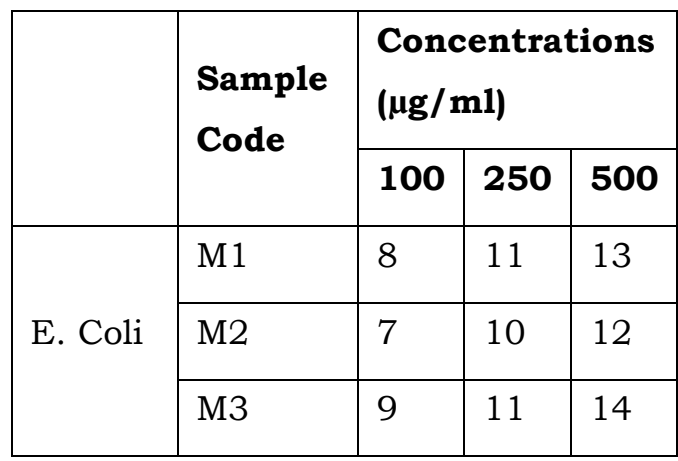

\begin{tabular}{|c|c|c|c|c|}
\hline \multirow[t]{2}{*}{ Organism } & \multirow{2}{*}{$\begin{array}{l}\text { Sample } \\
\text { Code }\end{array}$} & \multicolumn{3}{|c|}{$\begin{array}{l}\text { Concentrations } \\
(\mu \mathrm{g} / \mathrm{ml})\end{array}$} \\
\hline & & 100 & 250 & 500 \\
\hline \multirow{3}{*}{ S. aureus } & M1 & 10 & - & 14 \\
\hline & M2 & 9 & 11 & 12 \\
\hline & M3 & 10 & 12 & 14 \\
\hline
\end{tabular}

\begin{tabular}{|l|l|l|l|l|}
\hline \multirow{2}{*}{ Organism } & \multirow{2}{*}{$\begin{array}{l}\text { Sample } \\
\text { Code }\end{array}$} & \multicolumn{3}{|l|}{\begin{tabular}{l}
\multicolumn{3}{l|}{ Concentrations } \\
$(\boldsymbol{\mu g} / \mathbf{m l})$
\end{tabular}} \\
\cline { 3 - 5 } & & $\mathbf{1 0 0}$ & $\mathbf{2 5 0}$ & $\mathbf{5 0 0}$ \\
\hline \multirow{3}{*}{$\begin{array}{l}\text { Aspergillus } \\
\text { awamorii }\end{array}$} & M1 & 8 & 11 & 12 \\
\cline { 2 - 5 } & M2 & 7 & 12 & 13 \\
\cline { 2 - 5 } & M3 & 7 & 10 & 12 \\
\hline
\end{tabular}

The activity is shown by extracts of petroleum ether, dichloromethane and chloroform (M1 to M3) of G.mangostana . The antibacterial activity of the extracts at different concentrations was screened by disc diffusion technique and the zone of inhibition was measured in mm diameter.

From Table 1 and 2 it can be seen that the extract M1 and M3 showed strong antimicrobial activity against S. aureus than M2 at 500 $\mu \mathrm{g} / \mathrm{ml}$. But M1 did not show the inhibition zone at $250 \mu \mathrm{g} / \mathrm{ml}$ concentration. In case of activity of extract against E.coli, all the extracts were active at $500 \mu \mathrm{g} / \mathrm{ml}$. Extracts M2 have shown good inhibition zone against Aspergillus awamorii. 

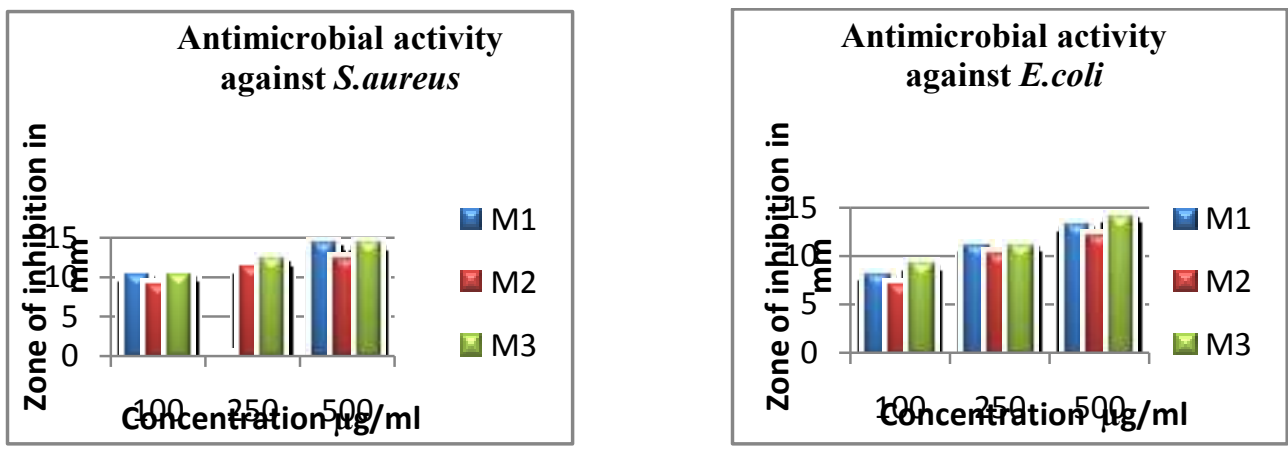

Figure1:Antimicrobial activity agains Figure2: Antimicrobial activity

S.aureus

against E.coli

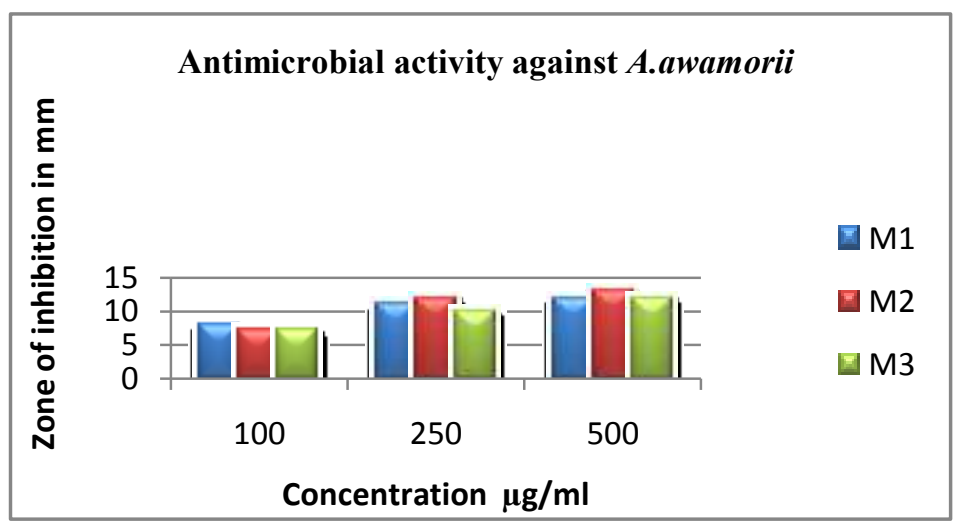

\section{Figure 3 : Antimicrobial activity against A.awamorii}

\section{Conclusion}

Plant essential oils and extracts have been used for long time, in food preservation, pharmaceuticals, alternative medicine and natural therapies. It is necessary to investigate such plants scientifically which have been used in traditional medicine to improve the quality of healthcare. Plant extracts are potential sources of novel antimicrobial compounds especially against bacterial pathogens. In vitro studies in this work showed that the plant extracts inhibited bacterial growth but their effectiveness varied. The antimicrobial activity of these plant extracts has been previously reviewed and classified as strong, medium or weak 
This in vitro study demonstrated that the folk medicine can be as effective as modern medicine to combat pathogenic microorganisms. The millenarian use of these plants in folk medicine suggests that they represent an economical and safe alternative to treat infectious diseases. It is clear from the results that, the extract acts as a good source of antimicrobial agent against various bacterial pathogens tested and exhibited broad spectrum of antibacterial activity.

Many medicinal plants have been found effective in the cure of bacterial diseases. Due to increasing antibiotic resistance in microorganisms and side effects of synthetic antibiotics medicinal plants are now gaining popularity in the treatment of bacterial infections. Medicinal plants are considered as clinically effective and safer alternatives to the synthetic antibiotics. Extensive research in the area of isolation and characterization of the active principles of these plants are required so that better, safer and cost effective drugs for treating bacterial infections can be developed.

\section{References:}

Prakash P and Gupta N,( 2005). Indian J Physiol Pharmacol., 49(2), 125 31.

Comer M and Debus E A, ( 1996). Partnership, Biotechnology, BioPharmaceuticals and Biodiversity,

Piddock K J V and Wise R, (1989). J Antimicrobial Chemotherapy, 23, 475-483.

Singh M, Chaudhry M A, Yadava J N S and Sanyal S C,(1992), J Antimicrobial Chemotherapy, 29, 159-168.

Mulligen M E, Murry-Leisure K A, Ribner B S, Standiford H C, John J F, Karvick J A, Kauffman C A and Yu V L,( 1993). American J Medicine, 94, 313-328.

Davis, J, (1994), Science, 264, 375-382. 
Robin E H, Anril W, Alexander M, Loeto M and Keith K, , 1998). Int J Infect Diseases, 3(1), 18-25.

Service R F, (1995), Science, 270, 724-727.

Agrawal P, Rai V and Singh R, B,( 1996), Int J Clin Pharm Thera., 34(8), 406-409.

Venugopal A, Dasani S and Rai S,( 2009). Electronic J Biology, 5(2), 4044.

Kalemba D and Kunicka A, (2003), Curr Med Chem., 10, 813 - 829.

Juliani H R and Simon J E, (2002) ASHS Press, Alexandria, V A pp. 575579.

Falerio M L, Miguel M G, Laderio F, Venancio F, Tavares R, Brito J C, Figueiredo A C, Barroso J G and Pedro L G,(2003). Antimicrobial Lett Appl Microbiol., 36, 35-40.

Jirovetz L, Buchbauer G, Shafi, M P and Kaniampady M M, (2003) Eur Food Res Technol., 217,120-124. 